\section{An updated systematic review on the coronavirus pandemic: lessons for psychiatry}

Braz J Psychiatry. 2020 May-Jun;42(3):330-331 doi:10.1590/1516-4446-2020-0975

\section{(cc) BY-NC}

Risk stratification always occurs in potentially lifethreatening scenarios so that the resources and attention of medical personnel are targeted at more objective goals, such as the infection itself, rather than comorbidities like mental disorders. However, some efforts have been made to address psychological and psychiatric issues during the pandemic. In one such case, on Jan 26, 2020 the National Health Commission of China published (in Chinese only) basic principles for emergency psychological crisis intervention during the COVID-19 outbreak.

We performed a systematic review according to Cochrane group recommendations, and the present report follows PRISMA guidelines. A total of ten articles were included. Every article was either based on (a) describing strategies for coping with the pandemic and/or (b) a more descriptive analysis of the overall clinical scenario, with emphasis in psychiatric comorbidities. Of the ten articles, seven were by Chinese groups, ${ }^{1-7}$ one was by an American group, ${ }^{8}$ one was by a Japanese group, ${ }^{9}$ and one was by a Korean group. ${ }^{10}$ The main findings are summarized in Table 1.
The main findings highlight the negative emotion and stress experienced by healthcare workers who treat infected patients. The main symptoms included de novo complaints of insomnia, anxiety, and feelings of hopeless, as well as the reactivation of previous disorders, such as depression, anxiety and even suicidal behavior. These mental health problems not only affect patients but also medical workers, which can lead to misunderstandings and poor decision making, and can also hinder the fight against COVID-19, as well as have lasting effects on individual well-being. It was also found that people with health anxiety tend to misinterpret benign bodily sensations and changes as dangerous, which increases hospital visits and, thus, the risk for infection itself. Some authors have focused on specific populations such as the homeless ${ }^{5}$ and older adults. ${ }^{6}$

Three important factors for overcoming the main difficulties in clinical practice emerge from reports on the Chinese mental health care response to the COVID-19 outbreak $^{1-7}:$ 1) multidisciplinary mental health teams (including psychiatrists, psychiatric nurses, clinical psychologists, and other mental health professionals) must be established; 2) up-to-date communication with reliable data about the COVID-19 outbreak is necessary; and 3) interventions (mainly psychological counseling) are needed for patients and healthcare providers directly involved in the outbreak (e.g., through electronic devices and apps).

Initial publications have addressed the overall psychological characteristics of patients and healthcare providers, as well as rapidly implemented interventions to cope with this catastrophic life-threatening scenario. Hopefully, the success of such efforts will become clear in the near future.

Table 1 Main findings for psychiatric issues during the COVID-19 pandemic

\begin{tabular}{|c|c|c|c|c|c|}
\hline Author & $\begin{array}{l}\text { Publication } \\
\text { date }\end{array}$ & Published as & Emphasis on & Core idea & Highlights for COVID-19 \\
\hline Asmundson ${ }^{8}$ & $\begin{array}{l}\text { March } \\
2020\end{array}$ & Editorial & $\begin{array}{l}\text { Health } \\
\text { anxiety }\end{array}$ & $\begin{array}{l}\text { People with high health anxiety } \\
\text { tend to misinterpret benign bodily } \\
\text { sensations and changes as } \\
\text { dangerous }\end{array}$ & $\begin{array}{l}\text { Anxiety is one of several psychological } \\
\text { factors that influence the way any given } \\
\text { person responds to a viral outbreak }\end{array}$ \\
\hline Tsai $^{5}$ & April 2020 & Letter & $\begin{array}{l}\text { Homeless } \\
\text { people }\end{array}$ & $\begin{array}{l}\text { Homeless patients generally } \\
\text { suffer from chronic illnesses or } \\
\text { critical conditions, which make } \\
\text { them vulnerable }\end{array}$ & $\begin{array}{l}\text { The increased potential exposure of } \\
\text { homeless people to COVID- } 19 \text { may } \\
\text { negatively affect their mental and } \\
\text { physical health }\end{array}$ \\
\hline Yang $^{6}$ & April 2020 & Correspondence & $\begin{array}{l}\text { Older } \\
\text { patients }\end{array}$ & $\begin{array}{l}\text { Older adults are particularly } \\
\text { vulnerable to psychiatric } \\
\text { symptoms during a pandemic }\end{array}$ & $\begin{array}{l}\text { Rapid viral transmission and high death } \\
\text { rates could exacerbate the risk of } \\
\text { mental health problems and worsen } \\
\text { existing psychiatric symptoms in older } \\
\text { adults }\end{array}$ \\
\hline Jiang $^{2}$ & $\begin{array}{l}\text { February } \\
2020\end{array}$ & Original article & $\begin{array}{l}\text { Intervention } \\
\text { strategies for } \\
\text { pandemics }\end{array}$ & $\begin{array}{l}\text { Psychological crisis intervention } \\
\text { may help medical workers, } \\
\text { patients, and others affected by a } \\
\text { pandemic }\end{array}$ & $\begin{array}{l}\text { Efficient methods of psychological crisis } \\
\text { intervention must be supported during } \\
\text { the outbreak }\end{array}$ \\
\hline $\mathrm{Xiao}^{3}$ & $\begin{array}{l}\text { February } \\
2020\end{array}$ & Correspondence & $\begin{array}{l}\text { Intervention } \\
\text { strategies for } \\
\text { pandemics }\end{array}$ & $\begin{array}{l}\text { Structured letter therapy may be a } \\
\text { feasible psychological intervention } \\
\text { approach in pandemics }\end{array}$ & $\begin{array}{l}\text { Remote written counseling may } \\
\text { become a new type of psychological } \\
\text { counseling mode in the context of } \\
\text { COVID-19 }\end{array}$ \\
\hline
\end{tabular}

Continued on next page 
Table 1 (continued)

\begin{tabular}{|c|c|c|c|c|c|}
\hline Author & $\begin{array}{l}\text { Publication } \\
\text { date }\end{array}$ & Published as & Emphasis on & Core idea & Highlights for COVID-19 \\
\hline Park $^{10}$ & $\begin{array}{l}\text { February } \\
2020\end{array}$ & Editorial & $\begin{array}{l}\text { Psychiatric } \\
\text { comorbidities }\end{array}$ & $\begin{array}{l}\text { Mental health problems in both } \\
\text { patients and healthcare workers } \\
\text { during a pandemic }\end{array}$ & $\begin{array}{l}\text { The increase in psychiatric conditions } \\
\text { (anxiety, mood disorders, and } \\
\text { increased feelings of fear, uncertainty, } \\
\text { and stigmatization) can be prevented by } \\
\text { medical and psychiatric treatment }\end{array}$ \\
\hline $\mathrm{Kang}^{4}$ & $\begin{array}{l}\text { February } \\
2020\end{array}$ & Correspondence & $\begin{array}{l}\text { Psychiatric } \\
\text { comorbidities }\end{array}$ & $\begin{array}{l}\text { Mental health response after a } \\
\text { public health emergency }\end{array}$ & $\begin{array}{l}\text { Assessing psychiatric symptoms as } \\
\text { well as developing rapid coping } \\
\text { strategies are musts during the } \\
\text { pandemic }\end{array}$ \\
\hline Shigemura $^{9}$ & $\begin{array}{l}\text { February } \\
2020\end{array}$ & Letter & $\begin{array}{l}\text { Psychiatric } \\
\text { comorbidities }\end{array}$ & $\begin{array}{l}\text { The mental/physical health } \\
\text { consequences of the pandemic } \\
\text { and the most vulnerable } \\
\text { populations should be focused on }\end{array}$ & $\begin{array}{l}\text { Fear of the unknown raises anxiety } \\
\text { levels in healthy individuals as well as } \\
\text { those with preexisting mental health } \\
\text { conditions }\end{array}$ \\
\hline Xiang $^{1}$ & $\begin{array}{l}\text { February } \\
2020\end{array}$ & Comment & $\begin{array}{l}\text { Psychiatric } \\
\text { comorbidities }\end{array}$ & $\begin{array}{l}\text { Mental health parallels between } \\
\text { COVID- } 19 \text { and the } 2003 \text { outbreak } \\
\text { of severe acute respiratory } \\
\text { syndrome (SARS) }\end{array}$ & $\begin{array}{l}\text { In any biological disaster, fear, } \\
\text { uncertainty, and stigmatization are } \\
\text { common and may act as barriers to } \\
\text { appropriate medical and mental health } \\
\text { interventions }\end{array}$ \\
\hline Zhou $^{7}$ & April 2020 & Letter & $\begin{array}{l}\text { Intervention } \\
\text { strategies }\end{array}$ & $\begin{array}{l}\text { The impact of psychological crisis } \\
\text { coping strategies }\end{array}$ & $\begin{array}{l}\text { Mental health is crucial for determining } \\
\text { better clinical outcomes for both } \\
\text { patients and medical staff. The authors } \\
\text { highlight self-help interventions and } \\
\text { online therapeutic strategies }\end{array}$ \\
\hline
\end{tabular}

Pedro Shiozawa, id Ricardo R. Uchida Departamento de Saúde Mental, Faculdade de Ciências Médicas da Santa Casa de São Paulo, São Paulo, SP, Brazil.

Submitted Mar 23 2020, accepted Mar 292020.

\section{Disclosure}

The authors report no conflicts of interest.

How to cite this article: Shiozawa P, Uchida RR. An updated systematic review on the coronavirus pandemic: lessons for psychiatry. Braz J Psychiatry. 2020;32: 330-331. http://dx.doi.org/10.1590/1516-4446-2020-0975

\section{References}

1 Xiang YT, Yang Y, Li W, Zhang L, Zhang Q, Cheung T, et al. Timely mental health care for the 2019 novel coronavirus outbreak is urgently needed. Lancet Psychiatry. 2020;7:228-9.

2 Jiang X, Deng L, Zhu Y, Ji H, Tao L, Liu L, et al. Psychological crisis intervention during the outbreak period of new coronavirus pneumonia from experience in Shanghai. Psychiatry Res. 2020;286: 112903.

3 Xiao C. A novel approach of consultation on 2019 novel coronavirus (COVID-19)-related psychological and mental problems: structured letter therapy. Psychiatry Investig. 2020;17:175-6.

4 Kang L, Li Y, Hu S, Chen M, Yang C, Yang BX, et al. The mental health of medical workers in Wuhan, China dealing with the 2019 novel coronavirus. Lancet Psychiatry. 2020;7:e14.

5 Tsai J, Wilson M. COVID-19: a potential public health problem for homeless populations. Lancet Public Health. 2020;5:e186-7.

6 Yang Y, Li W, Zhang Q, Zhang L, Cheung T, Xiang YT. Mental health services for older adults in China during the COVID-19 outbreak. Lancet Psychiatry. 2020;7:e19.

7 Zhou X. Psychological crisis interventions in Sichuan Province during the 2019 novel coronavirus outbreak. Psychiatry Res. 2020;286: 112895.

8 Asmundson GJ, Taylor S. How health anxiety influences responses to viral outbreaks like COVID-19: what all decision-makers, health authorities, and health care professionals need to know. J Anxiety Disord. 2020;71:102211.

9 Shigemura J, Ursano RJ, Morganstein JC, Kurosawa M, Benedek DM. Public responses to the novel 2019 coronavirus (2019-nCoV) in Japan: mental health consequences and target populations. Psychiatry Clin Neurosci. 2020;74:281-2.

10 Park SC, Park YC. Mental health care measures in response to the 2019 novel coronavirus outbreak in Korea. Psychiatry Investig. 2020;17:85-6. 